\title{
KNJIŽNIČNE USLUGE I SLUŽBE S GLEDIŠTA KORISNIKA - PRILOZI ZA BIBLIOGRAFIJU
}

\section{LIBRARY SERVICES FROM THE USERS' PERSPECTIVE - CONTRIBUTIONS TO THE BIBLIOGRAPHY}

\author{
Ljiljana Aleksić \\ Knjižnica Božidara Adžije \\ Knjižnice grada Zagreba \\ ljiljana.aleksic@kgz.hr \\ Silvija Zec \\ Knjižnica Božidara Adžije \\ Knjižnice grada Zagreb \\ silvija.zec@kgz.hr
}

\author{
UDK / UDC 011:001.89 \\ Stručni rad / Professional paper \\ Prihvaćeno / Accepted: 18. 5. 2017.
}

\section{Sažetak}

Bibliografija daje pregled znanstvenih i stručnih radova koji se bave istraživanjem knjižničnih usluga i službi iz perspektive korisnika u razdoblju od 1991. do kraja 2016. godine u svim vrstama knjižnica u RH osim školskih knjižnica. Pregledani su i popisani članci, sažeci, prikazi i izlaganja na posterima uglavnom domaćih autora izašli u hrvatskim časopisima, članci u zbornicima, diplomski, magistarski i doktorski radovi, kao i mrežno dostupna istraživanja. Svi radovi razvrstani su u tematske kategorije. U zaključku rad donosi analizu učešća pojedinih vrsta knjižnica u navedenim istraživanjima, najzastupljenije teme istraživanja, kao i najčešće korištene metode za prikupljanje podataka unutar navedenog razdoblja.

Ključne riječi: bibliografija, knjižnične usluge, knjižnice, istraživanje korisnika, kvantitativne i kvalitativne metode

Vjesnik bibliotekara Hrvatske 60, 2-3(2017), 317-339

ISSN 0507-1925

(C) VBH 2017. 


\section{Summary}

The bibliography provides an overview of the scientific and professional papers dealing with the research of the library services and departments from the users' perspective in the period from 1991 to the end of 2016 in all types of libraries in the Republic of Croatia, with the exception of school libraries. The research included articles, summaries, reviews, and presentations on posters, mostly by the domestic authors, that have been published in Croatian library journals, proceedings, graduate, master and doctoral theses, and also the available online researches. All papers were later classified in several thematic categories. In conclusion, the paper provides an analysis of the participation of certain types of libraries in the aforementioned researches, the most frequent research topics as well as the most frequently used methods for collecting data within the given time period.

Keywords: bibliography, library services, libraries, user surveys, quantitative and qualitative methods

\section{Uvod}

Bibliografija sadrži popis znanstvenih i stručnih radova koji se bave istraživanjem knjižničnih usluga iz perspektive korisnika u narodnim, visokoškolskim i specijalnim knjižnicama, Gradskoj i sveučilišnoj knjižnici Osijek, sveučilišnim knjižnicama u Rijeci i Splitu, Znanstvenoj knjižnici Zadar i Nacionalnoj i sveučilišnoj knjižnici Zagreb, objavljenih u razdoblju od 1991. do kraja 2016. godine.

U tu svrhu pregledani su i popisani članci, sažeci, prikazi i izlaganja na posterima uglavnom domaćih autora izašli u hrvatskim časopisima (Vjesnik bibliotekara Hrvatske, Knjižničarstvo, Libellarium, Svezak, Glasnik Društva bibliotekara Split, Godišnjak Gradske knjižnice Metel Ožegović, Muzeologija, Podravina), članci u zbornicima (Arhivi, knjižnice, muzeji, Dani specijalnih i visokoškolskih knjižnica, Slobodan pristup informacijama, Knjižnica, Dani specijalnoga knjižničarstva Hrvatske, zbornik 400. obljetnica Nacionalne i sveučilišne knjižnice u Zagrebu, zbornik Slobodan pristup informacijama u službi kulturnog razvitka i dva zbornika s međunarodnih skupova), magistarski i doktorski radovi te mrežno dostupna istraživanja. Podaci navedeni u bibliografskom popisu preuzeti su po neposrednom uvidu u radove (de visu). Diplomski radovi, koji su također uvršteni u bibliografiju, dijelom su pregledani kao cjelovit tekst i navedeni su kao mrežno dostupni, a neki su pregledani preko sažetaka u bazi CROSBI $^{1}$ i također navedeni jer je bila jasna njihova metodologija.

Osnovna je namjera bibliografije okupiti na jednome mjestu one znanstvene i stručne radove koji se bave istraživanjem korisnika - zadovoljstvom i percepcijom kvalitete knjižničnih usluga, informacijskom službom, čitateljskim intere-

1 Hrvatska znanstvena bibliografija [citirano: 2017-05-02]. Dostupno na http://beta.bib.irb.hr/ 
sima i informacijskim potrebama korisnika, korištenjem pojedinih usluga, kao i informacijskom pismenošću i informacijskim ponašanjem korisnika. Stoga smo u bibliografiju, uz istraživanja korisnika koja se služe primarnim podacima (prikupljeni metodom ankete, intervjua, fokus-grupa ili promatranja), uvrstili i radove koji se služe sekundarnim podacima o korištenosti pojedinih usluga (kvantitativna analiza obrazaca za tematske upite ili narudžbenice za posudbu građe). Kako je korisnički aspekt važan u traženju informacija, u obzir smo uzeli i istraživanja o korisničkom ponašanju prilikom izbora knjižnice kao informacijskog kanala (među ostalim informacijskim kanalima), kao i ponašanje prilikom korištenja informacijskih izvora (naročito elektroničkih). Ova istraživanja donose i nove metodologije, kao što su studije uporabljivosti, analize posjećenosti mrežnih mjesta i analize log-datoteka.

Sljedeći kriterij u bibliografiji bio je razvrstavanje radova po temama. Kao polazište za osmišljavanje tematskog popisa poslužila je klasifikacijska shema tema autora Järvelina i Vakkarija. ${ }^{2}$ Tu klasifikaciju nismo preuzeli u potpunosti, nego smo konačan popis tema oblikovali i prilagodili onim korisničkim aspektima knjižničnih usluga i službi koji su se nametnuli kao relevantni na temelju pregledanih istraživanja. Također, radi ekonomičnosti, neke smo teme objedinili u jednu (npr. informacijska pismenost i informacijsko ponašanje).

Radovi u bibliografiji popisani su u deset tema s dodatnim objašnjenjima uz neke od tema. Ukoliko je neki rad obrađivao dvije ili više tema, dodijeljen je onoj temi koja je prevladavala u samom radu.

\section{TEME:}

Posudba i međuknjižnična posudba

Knjižnične zbirke/građa

Informacijska služba

Čitateljski interesi i informacijske potrebe korisnika

Zadovoljstvo korisnika i percepcija kvalitete knjižničnih službi i usluga

Elektroničke usluge

Edukacija korisnika

Razne druge aktivnosti informativne službe

Informacijska pismenost i informacijsko ponašanje

Zgrada i prostori knjižnice

\footnotetext{
2 Järvelin, Kalervo; Pertti Vakkari. Appendix 1: The classification scheme. 1993. [citirano: 2017-05-05]. // International library and information science research : a comparison of national trends / by Maxine K. Rochester and Pertti Vakkari [on behalf of IFLA's] Section on Library Theory and Research. [S. 1.] : Interanational Federation of Library Associations and Instititions, cop. 2003. (IFLA professional reports ; nr. 82). Str. 27-28. Dostupno na http://www.ifla.org/VII/ s24/pub/iflapr-82-e.pdf.
} 


\section{Bibliografija}

\subsection{Posudba i međuknjižnična posudba}

(raspoloživost/dostupnost građe, mogućnost rezerviranja, radno vrijeme)

Avalon, Sonja; Dunja Marija Gabriel. Prikaz podataka o međuknjižničnoj posudbi knjiga iz fonda NSK u Zagrebu kao jedan od pokazatelja kvalitete nabave knjižnične građe. // Knjižnice: kamo i kako dalje? : pohrana i zaštita knjižnične građe, profesija "knjižničar"???, usluge i korisnici : zbornik radova / 12. dani specijalnih i visokoškolskih knjižnica, Opatija, 11.-14. svibnja 2011. ; uredile Alisa Martek i Elizabeta Rybak Budić ; [prijevod na engleski jezik Tea Fluksi]. Zagreb: Hrvatsko knjižničarsko društvo, 2013. Str. 373-389.

Čonč, Tea. Međuknjižnična posudba i dostava dokumenata Knjižnice Filozofskog fakulteta u Zagrebu ili kako ustrojiti službu. // Vjesnik bibliotekara Hrvatske 54, 3(2011), 127-146. [citirano: 2017-05-02] Dostupno i na http://www.hkdrustvo.hr/vbh/broj/104.

Čonč, Tea. Tko su i što trebaju korisnici međuknjižnične posudbe u društveno-humanističkoj knjižnici?: analiza korisničkih zahtjeva u Knjižnici Filozofskog fakulteta u Zagrebu. // Knjižnice: kamo i kako dalje? : pohrana i zaštita knjižnične građe, profesija "knjižničar"???, usluge i korisnici : zbornik radova / 12. dani specijalnih i visokoškolskih knjižnica, Opatija, 11.-14. svibnja 2011. ; uredile Alisa Martek i Elizabeta Rybak Budić ; [prijevod na engleski jezik Tea Fluksi]. Zagreb: Hrvatsko knjižničarsko društvo, 2013. Str. 390-404.

Golubović, Vesna. Razvoj i uloga međuknjižnične posudbe: magistarski rad. Zagreb: vlast. nakl., 2009.

Golubović, Vesna; Jadranka Lasić-Lazić. Međuknjižnična posudba - stanje i mogućnosti. // Vjesnik bibliotekara Hrvatske 54, 3(2011), 107-126. [citirano: 2017-05-02] Dostupno i na http://www.hkdrustvo.hr/vbh/broj/104.

Petrak, Jelka; Lidija Marković. Međuknjižnična posudba između Središnje medicinske knjižnice i (bio)medicinskih knjižnica u Hrvatskoj. // Vjesnik bibliotekara Hrvatske 45, 1/2(2002), 41-49.

\subsection{Knjižnične zbirke/građa}

(brojnost, aktualnost, očuvanost i korištenje pojedinih knjižničnih zbirki npr. zbirka udžbenika, multimedijske zbirke, filmske i druge zbirke)

Cej, Višnja; Tea Grašić-Kvesić; Tomislav Silić. Audiovizualna, multimedijalna i elektronička građa : istraživanje učestalosti korištenja. // Vjesnik bibliotekara Hrvatske 56, 4(2013), 145-168. [citirano: 2017-05-02] Dostupno i na http:// www.hkdrustvo.hr/vbh/broj/11. 
Duić, Mirko. Filmske zbirke u hrvatskim narodnim knjižnicama : doktorski rad. Zadar : vlast. nakl., 2015.

Grečl, Biserka. Stavovi studenata o knjižničnoj građi u Nacionalnoj i sveučilišnoj knjižnici u Zagrebu. // Knjižnice: kamo i kako dalje? : knjižnice i očuvanje kulturne baštine, knjižnice bez granica: digitalni repozitoriji, knjižnični softveri : zbornik radova / 11. dani specijalnih i visokoškolskih knjižnica, Opatija, 1.-4. travnja 2009.; uredile Tamara Krajna i Alisa Martek ; [prijevod na engleski Tea Fluksi]. Zagreb : Hrvatsko knjižničarsko društvo, 2010. Str. 66-75.

Mišetić, Marijana; Nevia Raos. Zbirka u zbirci : zbirka udžbenika za učenje talijanskog jezika u zbirci za talijanistiku Knjižnice Filozofskog fakulteta u Zagrebu. // 15. seminar Arhivi, knjižnice, muzeji : mogućnosti suradnje u okruženju globalne informacijske infrastrukture : zbornik radova / uredili Damir Hasenay i Maja Krtalić. Zagreb : Hrvatsko knjižničarsko društvo, 2012. Str. 371-379.

Peradenić-Kotur, Blaženka; Irena Pilaš. Zbirka službenih publikacija NSK i potrebe korisnika. // Korisnici u 21. stoljeću - izazov za knjižničarsku struku : radni materijali / 31. skupština Hrvatskoga knjižničarskog društva, međunarodni skup, Zadar, 7. - 10. listopada 1998. [Zagreb?] : Hrvatsko knjižničarsko društvo, [1998.?]. Str. 97-98.

Peranić, Ana. Bjelovariana: istraživanje korisnika i korištenja zavičajne zbirke Narodne knjižnice „Petar Preradović“ Bjelovar. // Svezak: Časopis Društva knjižničara Bilogore, Podravine i Kalničkog prigorja 17, 17(2015) 16-17. [citirano: 2017-05-02] Dostupno i na http://www.drustvo-knjiznicara-bpkp.hr/ svezak/svezak17/Svezak_17_2015.pdf.

Pikić, Aleksandra. Statistika potražnje i korištenja tiskanih časopisa knjižnica Filozofskog fakulteta Sveučilišta u Zagrebu. // 13. seminar Arhivi, knjižnice, muzeji : mogućnosti suradnje u okruženju globalne informacijske infrastrukture : zbornik radova / uredile Mirna Willer i Sanjica Faletar Tanacković. Zagreb, 2010. Str. 292-305.

Tokić, Ivo. Spajanje knjižničnih fondova pri selidbi knjižnica: magistarski rad. Zagreb: vlast. nakl., 2001.

\subsection{Informacijska služba}

(stručnost i komunikacijske vještine knjižničara, rješavanje različitih vrsta upita, posebno tematskih upita, ponašanje korisnika prilikom korištenja te usluge)

Bačić, Mira; Zagorka Majstorović. Nacionalna i sveučilišna knjižnica: stanje i perspektive tematskih pretraživanja za korisnike. // 7. seminar Arhivi, knjižnice, muzeji : mogućnosti suradnje u okruženju globalne informacijske infra- 
strukture : zbornik radova / uredila Tinka Katić. Zagreb : Hrvatsko knjižničarsko društvo, 2004. Str. 47-52.

Baj, Igor; Vesna Golubović; Marko Orešković. Istraživanje korisnika Nacionalne i sveučilišne knjižnice u Zagrebu o novom obliku usluge : tematsko pretraživanje. // Vjesnik bibliotekara Hrvatske 56, 4(2013), 107-128. [citirano: 201705-02] Dostupno i na http://www.hkdrustvo.hr/vbh/broj/111.

Belan-Simić, Alemka; Dragica Previšić. Kako korisnici ocjenjuju pomoć bibliotekara u rješavanju tematskih zahtjeva : istraživanje provedeno u knjižnici Božidara Adžije u Zagrebu. // Vjesnik bibliotekara Hrvatske 41, 1-4(1998 [i.e.1999]), 31-40.

Belan-Simić, Alemka; Dragica Previšić. Koliko smo uspješni u rješavanju tematskih izlaganja. // Korisnici u 21. stoljeću - izazov za knjižničarsku struku : radni materijali / 31. skupština Hrvatskoga knjižničarskog društva, međunarodni skup, Zadar, 7. - 10. listopada 1998. [Zagreb?] : Hrvatsko knjižničarsko društvo, [1998.?]. Str. 70.

Bubić, Zdenka; Maja Šeferov. Jezična i sadržajna analiza korisničkih upita u narodnim knjižnicama. // Vjesnik bibliotekara Hrvatske 44, 1-4(2001), 145-156.

Golenko, Dejana. Vrednovanje rada knjižničara: na primjeru knjižnice Pravnog fakulteta u Rijeci. // Uspostava kvalitete u specijalnim i visokoškolskim knjižnicama - knjižnice u bolonjskom okruženju : zbornik radova / 10. dani specijalnih i visokoškolskih knjižnica, Opatija, 24.-26. travnja 2008. ; uredile Irena Pilaš i Alisa Martek. Zagreb : Hrvatsko knjižničarsko društvo, 2009. Str. 176184.

Grečl, Biserka. Tematska pretraživanja u Nacionalnoj i sveučilišnoj knjižnici u Zagrebu u odsjeku u središnjoj službi čitaonica. // Knjižnice: kamo i kako dalje? : pohrana i zaštita knjižnične građe, profesija "knjižničar"???, usluge i korisnici : zbornik radova / 12. dani specijalnih i visokoškolskih knjižnica, Opatija, 11.-14. svibnja 2011. ; uredile Alisa Martek i Elizabeta Rybak Budić ; [prijevod na engleski jezik Tea Fluksi]. Zagreb: Hrvatsko knjižničarsko društvo, 2013. Str. 348-357.

Katić, Dubravka; Emilija Pezer. Odnos knjižničarskog osoblja i korisnika u Gradskoj knjižnici i čitaonici Vinkovci. // Korisnici u 21. stoljeću - izazov za knjižničarsku struku : radni materijali / 31. skupština Hrvatskoga knjižničarskog društva, međunarodni skup, Zadar, 7. - 10. listopada 1998. [Zagreb?] : Hrvatsko knjižničarsko društvo, [1998.?]. Str. 88-89.

Lukačević, Srđan. Komunikacijske vještine knjižničara : primjer Gradske i sveučilišne knjižnice u Osijeku: diplomski rad [citirano 2017-05-02]. Osijek : vlast. nakl., 2010. Dostupno i na http://repo.ffos.hr/867/.

Lukačević, Srđan; Kornelija Petr Balog. Trebamo li mijenjati svoje komunikacijske vještine? : primjer Gradske i sveučilišne knjižnice Osijek. // Vjesnik 
bibliotekara Hrvatske 56, /2(2013), 153-169. [citirano: 2017-05-02] Dostupno i na http://www.hkdrustvo.hr/vbh/broj/109.

Lukačević, Srđan; Kornelija Petr Balog; Dubravka Pađen Farkaš. Asertivnost u knjižničnom okruženju: primjer Gradske i sveučilišne knjižnice Osijek. // Libellarium 9, 1(2016), 89-110. [citirano: 2017-05-02] Dostupno i na http:// www.libellarium.org/index.php/libellarium/article/view/245.

Siminiati Violić, Žana. Uloga knjižničara - predmetnih stručnjaka u bolonjskom procesu u Umjetničkoj akademiji u Splitu. Glasnik Društva bibliotekara Split. 9(2011), 21-32.

\section{4. Čitateljski interesi i informacijske potrebe korisnika} (čitateljski interesi i navike, informacijske potrebe pojedinih skupina korisnika - npr. studenti, djeca, slijepe i slabovidne osobe, nacionalne manjine, zatvorenici)

Bačić, Edita; Gordana Miolin. // Dostupnost i korištenje Internet-kioska i Euro-polica u splitskim knjižnicama. // Slobodan pristup informacijama : 2. i 3. okrugli stol : zbornik radova / uredile Alemka Belan-Simić i Aleksandra Horvat. Zagreb : Hrvatsko knjižničarsko društvo, 2004. Str. 70-77.

Bajić, Meri. Informacijske potrebe i čitateljske navike zatvorenika: diplomski rad [citirano 2017-05-02]. Osijek : vlast. nakl., 2015. Dostupno i na http://repo. ffos.hr/1910/.

Badurina, Boris; Darko Lacović; Snježana Stanarević. Informacijske potrebe i ponašanje pripadnika mađarske jezične manjine u Osječko-baranjskoj županiji. // Knjižnica: komunikacijsko i multikulturalno središte lokalne zajednice : zbornik radova : 8. savjetovanje za narodne knjižice u Republici Hrvatskoj / [priredila Jelica Leščić]. - Zagreb : Nacionalna i sveučilišna knjižnica, 2012. Str. 285-310.

Bučević-Sanvincenti, Lorenka. Dileme današnjeg djeteta - knjiga ili kompjutor. // Korisnici u 21. stoljeću - izazov za knjižničarsku struku : radni materijali / 31. skupština Hrvatskoga knjižničarskog društva, međunarodni skup, Zadar, 7. - 10. listopada 1998. [Zagreb'] : Hrvatsko knjižničarsko društvo, [1998.?] Str. 71-72.

Bučević-Sanvicenti, Lorenka. Dvojba današnjeg djeteta: knjiga ili računalo? // Vjesnik bibliotekara Hrvatske 42, 1/4(1999), 71-78.

De Villa, Sandra. Zatvorske knjižnice u Republici Hrvatskoj : magistarski rad [citirano 2017-05-02]. Zagreb : vlast. nakl., 2007. Dostupno i na http://darhiv. ffzg.unizg.hr/5765/1/Zatvorske\%20knji\%C5\%BEnice\%2C\%20Borna $\% 20$ Mesi\%C4\%87.\%20Zavr\%C5\%A1ni\%20rad.pdf. 
Dragija Ivanović, Martina; Nives Tomašević. Slobodno vrijeme i čitanje. // Međunarodni interdisciplinarni stručni skup Knjiga i slobodno vrijeme: zbornik radova / [uredništvo Elli Pecotić, Snježana Buczkowska, Katarina Krolo Žužul]. Split : Gradska knjižnica Marka Marulića, 2011. Str. 32-42.

Eleta, Nada. Interesi i potrebe korisnika treće životne dobi. // Godišnjak Gradske knjižnice Metel Ožegović, 2(1998), 153-156.

Eleta, Nada. Fondovi u narodnim knjižnicama. što sadrže, a što se traži? (Sažetak izlaganja) (29. Skupština Hrvatskog bibliotekarskog društva, Bizovačke toplice, 1994.). // Vjesnik bibliotekara Hrvatske 37, 3/4(1994), 101-105.

Faletar Tanacković, Sanjica; Darko Lacović; Snježana Stanarević. Multikulturalne knjižnične usluge: istraživanje informacijskih potreba i ponašanja pripadnika jezičnih manjina u Osječko-baranjskoj županiji. // Vjesnik bibliotekara Hrvatske 54, 4(2011), 49-94. [citirano: 2017-05-02] Dostupno i na http://www. hkdrustvo.hr/vbh/broj/105.

Faletar Tanacković, Sanjica; Andrea Plavšić; Snježana Stanarević Katavić. Informacijske potrebe i ponašanje gluhoslijepih osoba : pilot istraživanje. // Vjesnik bibliotekara Hrvatske 56, 4(2013), 179-202. [citirano: 2017-05-02] Dostupno i na http://www.hkdrustvo.hr/vbh/broj/11.

Grbin, Tatjana; Milojka Skokandić. Djeca korisnici izazov i budućnost knjižničarstva. // Korisnici u 21. stoljeću - izazov za knjižničarsku struku : radni materijali / 31. skupština Hrvatskoga knjižničarskog društva, međunarodni skup, Zadar, 7. - 10. listopada 1998. [Zagreb?] : Hrvatsko knjižničarsko društvo, [1998.?]. Str. 82-83.

Grubačević, Ivana: Informacijske potrebe korisnika u narodnim knjižnicama primjer Gradske knjižnice Velika Gorica : diplomski rad [citirano: 2017-05-02]. Zagreb, vlast. nakl., 2015. Dostupno i na http://darhiv.ffzg.unizg.hr/5782/1/ Ivana-Grubacevic-diplomski-rad.pdf.

Ivanović, Marija. Odnos adolescenata prema fondu narodne knjižnice (s apekta udovoljavanja čitateljskih interesa i informacijskih potreba) : magistarski rad. Zagreb : vlast. nakl., 1993.

Kovačević, Jasna. Utjecaj knjižničnih programa na posudbu knjiga i čitanje : doktorski rad. Zadar : vlast. nakl., 2015.

Marasović, Ivana. Dostupnost informacija slijepim i slabovidnim osobama: diplomski rad. Zadar : vlast. nakl., 2014.

Matejčić, Samanta. Knjižnične službe i usluge za posebne skupine korisnika u Istri : magistarski rad. Zagreb : vlast. nakl., 2006.

Medak, Antonija. Kultura čitanja i slobodno vrijeme mladih u knjižnici: diplomski rad. Zadar : vlast. nakl., 2010.

Miolin, Gordana. Gradska knjižnica Marka Marulića u Splitu - multikulturalno središte otvoreno za pripadnike nacionalnih manjina. // Knjižnica: komunika- 
cijsko i multikulturalno središte lokalne zajednice : zbornik radova : 8. savjetovanje za narodne knjižice u Republici Hrvatskoj / [priredila Jelica Leščić]. - Zagreb : Nacionalna i sveučilišna knjižnica, 2012. Str. 323-330.

Pavlinić, Silva; Jasna Horvat. Istraživanje potreba korisnika Gradske i sveučilišne knjižnice Osijek. // Vjesnik bibliotekara Hrvatske 41, 1/4(1998), 41-60.

Peroš, Ivan. Čitateljski interesi i navike mladih u digitalnom dobu kao polazište za usluge narodnih knjižnica: diplomski rad [citirano: 2017-05-02]. Zadar : vlast. nakl., 2016. Dostupno i na https://repozitorij.unizd.hr/islandora/object/ unizd:151/datastream/PDF/download.

Pikić, Aleksandra. Potrebe studenata s invaliditetom Filozofskog fakulteta u Zagrebu za prilagođenim knjižničnim uslugama. // Knjižnice: kamo i kako dalje? : pohrana i zaštita knjižnične građe, profesija "knjižničar"???, usluge i korisnici : zbornik radova / 12. dani specijalnih i visokoškolskih knjižnica, Opatija, 11.-14. svibnja 2011. ; uredile Alisa Martek i Elizabeta Rybak Budić ; [prijevod na engleski jezik Tea Fluksi]. Zagreb: Hrvatsko knjižničarsko društvo, 2013. Str. 239-25.

PRIMJENA istraživanja u promicanju pismenosti i čitanja u knjižnicama [Elektronička građa] : smjernice za knjižničare / priredile Lesley Farmer i Ivanka Stričević ; [s engleskog prevela Ivana Faletar]. Tekstovni podaci. Zagreb : Hrvatsko knjižničarsko društvo, 2012. (Elektronička izdanja Hrvatskoga knjižničarskog društva, ISSN 1846-5447 ; knj. 5) [citirano: 2017-05-02]. Dostupno na http://www.hkdrustvo.hr/hr/izdanja/kategorija/elektronicka.

Radmilović, Dino. Informacijske potrebe i ponašanje korisnika narodnih knjižnica u Hrvatskoj: informacije o Europskoj Uniji: diplomski rad [citirano: 201705-02]. Osijek : vlast. nakl., 2014. Dostupno i na http://repo.ffos.hr/1778/.

Sabolović-Krajina, Dijana. Čitateljske navike tinejdžera u Hrvatskoj (Sažetak izlaganja) ( 8. europska konferencija o čitanju, Malmö, 2. do 4. kolovoza 1993.). // Vjesnik bibliotekara Hrvatske 34, 1/4(1993), 59-66.

Stričević, Ivanka; Srećko Jelušić. Informacijske potrebe i čitateljski interesi građana Hrvatske. // Međunarodni interdisciplinarni stručni skup Knjiga i slobodno vrijeme: zbornik radova / [uredništvo Elli Pecotić, Snježana Buczkowska, Katarina Krolo Žužul]. Split : Gradska knjižnica Marka Marulića, 2011. Str. 16-31.

Stričević, Ivanka. Utvrđivanje informacijskih potreba i čitateljskih interesa mladeži u narodnoj knjižnici : doktorska disertacija. Zagreb : vlast. nakl., 2006.

Šehić, Silvana. Usluge sveučilišnih i visokoškolskih knjižnica za slijepe i slabovidne studente: diplomski rad [citirano 2017-05-02]. Osijek : vlast. nakl., 2013. Dostupno i na http://repo.ffos.hr/1453/.

Šimić, Sonja. Koliko poznajem i koristim svoju dječju knjižnicu? // Narodne knjižnice kao treći prostor: zbornik radova : 9. Savjetovanje za narodne knjiž- 
nice u republici Hrvatskoj / [uredile Dunja Marija Gabriel, Jelica Leščić]. Zagreb: Nacionala i sveučilišna knjižnica, 2015. Str. 341-350.

Tica, Milka. Uzorci označivanja književnih vrsta u narodnoj knjižnici : magistarski rad. Zagreb : vlast. nakl., 1995.

Tomašević, Nives. Istraživanje stajališta o čitanju i njihov utjecaj na nakladništvo: ocjena zainteresiranosti za književne vrste. // Libellarium, 1, 2(2008), 221-241. [citirano: 2017-05-02] Dostupno i na http://www.libellarium.org/index.php/libellarium/article/view/131/131.

Vrana, Radovan; Jasna Kovačević. Položaj knjižnice u umreženom društvu. // Vjesnik bibliotekara Hrvatske 53, 3/4(2010), 25-41. [citirano: 2017-05-02] Dostupno i na http://www.hkdrustvo.hr/vbh/broj/102.

\subsection{Zadovoljstvokorisnikaipercepcijakvaliteteknjižničnihslužbiiusluga} (zadovoljstvo korisnika, percepcija kvalitete svih knjižničnih službi i usluga)

Aleksić, Ljiljana; Dunja Seiter-Šverko. Vrednovanje nacionalne i sveučilišne knjižnice u Zagrebu s gledišta korisnika. // Vjesnik bibliotekara Hrvatske 57, 4(2014), 1-44. [citirano: 2017-05-02] Dostupno i na http://www.hkdrustvo.hr/ $\mathrm{vbh} / \mathrm{broj} / 113$.

Alijević, Sanja. Istraživanje korisničkih potreba u dječjoj knjižnici: diplomski rad. Zadar : vlast. nakl., 2010.

Analiza rezultata istraživanja o zadovoljstvu korisnika uslugama Sveučilišne knjižnice Rijeka [citirano: 2017-05-02]. Dostupno na http://www.svkri.uniri. $\mathrm{hr} /$ images/dokumenti/analizarezultataistrazivanja2013.pdf.

Anketno istraživanje zadovoljstva građana/ki Poreštine uslugama Gradske knjižnice Poreč [citirano: 2017-05-02]. Dostupno na http://www.knjiznicaporec.hr/ prva.aspx ?tranica $=1352 \&$ pid $=3541 \& \mathrm{j}=\mathrm{CRO}$.

Badurina, Boris; Martina Dragija-Ivanović; Tatjana Aparac-Jelušić. Knjižnične usluge, korisnici i korištenje u novoj Gradskoj knjižnici Zadar [citirano: 201705-02]. Dostupno na http://www.gkzd.hr/pdf/dokumenti/istrazivanje_korisnika_2001.pdf.

Benić, Danijela. Istraživanje zadovoljstva korisnika Gradske knjižnice u Belom Manastiru : diplomski rad [citirano: 2017-05-02]. Osijek, 2013. Dostupno i na http://repo.ffos.hr/1373/.

Cvetnić Kopljar, Marija. Istraživanje zadovoljstva korisnika odjela periodike knjižnice Pravnog fakulteta u Zagrebu. // Vjesnik bibliotekara Hrvatske 45, 3/4(2002), 195-206.

Črnjar, Ljiljana; Gordana Jerolimov-Beviakva. Vrednovanje knjižničnih usluga u Gradskoj biblioteci Rijeka. // Korisnici u 21. stoljeću - izazov za knjižničarsku struku : radni materijali / 31. skupština Hrvatskoga knjižničarskog društva, 
međunarodni skup, Zadar, 7. - 10. listopada 1998. [Zagreb?] : Hrvatsko knjižničarsko društvo, [1998.?]. Str. 77-78.

Dragija Ivanović, Martina. Vrednovanje utjecaja knjižnice na ruralnu otočnu zajednicu : doktorska disertacija. Zadar : vlast. nakl., 2012.

Dukić, Gordana; Sanda Hasenay; Svjetlana Mokriš Marendić. Analiza zadovoljstva korisnika/studenata u knjižnicama Prehrambeno-tehnološkog i Pravnog fakulteta te u Gradskoj i sveučilišnoj knjižnici Osijek. // Vjesnik bibliotekara Hrvatske 52, 1/4(2009), 172-187. [citirano: 2017-05-02] Dostupno i na http:// www.hkdrustvo.hr/vbh/broj/99.

Erl Šafar, Marija. Razvoj pokretnih knjižnica u Hrvatskoj : doktorska disertacija. Zagreb : vlast. nakl., 2013.

Frigo Haltrich, Irena. Istraživanje stavova korisnika prema novim uslugama: knjižnica Fakulteta političkih znanosti. // Knjižnice: kamo i kako dalje? : članstvo u EU - knjižničari gdje smo?, produktivnost znanstvene zajednice, obrazovanje korisnika, knjižnice u vremenu recesije - kako preživjeti ?: zbornik radova / 13. dani specijalnih i visokoškolskih knjižnica, Opatija, 15.-18. svibnja 2013. ; uredile Ivana Hebrang Grgić i Vesna Špac.; [prijevod na engleski jezik Tea Fluksi]. Zagreb : Hrvatsko knjižničarsko društvo, 2014. Str. 346-355.

Janeković, Andrea. Ispunjavanje potreba korisnika putem upravljanja ukupnom kvalitetom : istraživanje korisnika. // Korisnici u 21. stoljeću - izazov za knjižničarsku struku : radni materijali / 31. skupština Hrvatskoga knjižničarskog društva, međunarodni skup, Zadar, 7. - 10. listopada 1998. [Zagreb?] : Hrvatsko knjižničarsko društvo, [1998.?]. Str. 87.

Knežević, Božana. Istraživanje zadovoljstva korisnika knjižnice Prehrambeno-tehnološkoga fakulteta u Osijeku: diplomski rad [citirano 2017-05-02]. Osijek : vlast. nakl., 2014. Dostupno i na https://repozitorij.ffos.hr/en/islando$\mathrm{ra} /$ object/ffos\%3A880/datastream/PDF/view.

Knežević, Ivana; Marina Vinaj. Analiza korisnika Knjižnice muzeja Slavonije Osijek: kome je, uistinu, namijenjena muzejska knjižnica. // Knjižnice: kamo i kako dalje? : pohrana i zaštita knjižnične građe, profesija "knjižničar"???, usluge i korisnici : zbornik radova / 12. dani specijalnih i visokoškolskih knjižnica, Opatija, 11.-14. svibnja 2011. ; uredile Alisa Martek i Elizabeta Rybak Budić ; [prijevod na engleski jezik Tea Fluksi]. Zagreb: Hrvatsko knjižničarsko društvo, 2013. Str. 227-238.

Kos, Stela; Mila Perasović. Korisnici i usluge Knjižnice Filozofskog fakulteta Sveučilišta u Zagrebu. // Knjižnice: kamo i kako dalje? : pohrana i zaštita knjižnične građe, profesija "knjižničar"???, usluge i korisnici : zbornik radova / 12. dani specijalnih i visokoškolskih knjižnica, Opatija, 11.-14. svibnja 2011. ; uredile Alisa Martek i Elizabeta Rybak Budić ; [prijevod na engleski jezik Tea Fluksi]. Zagreb: Hrvatsko knjižničarsko društvo, 2013. Str. 215-226. 
Kovačević, Jasna; Radovan Vrana. Pogled na knjižnične usluge iz perspektive korisnika. // Vjesnik bibliotekara Hrvatske 58, 1/2(2015), 135-160. [citirano: 2017-05-02] Dostupno i na http://www.hkdrustvo.hr/vbh/broj/114.

Lisek, Jadranka. Prema modelu središnje visokoškolske knjižnice za područje elektrotehnike u Hrvatskoj: magistarski rad. Zagreb: vlast. nakl., 2000.

Masnov, Vanja. Korisnici visokoškolske agronomske knjižnice : magistarski rad. Zagreb : vlast. nakl., 2011.

Matković Mikulčić, Katja; Ivana Grubačević; Morana Peranić. Neka se glas korisnika čuje! // Narodne knjižnice kao treći prostor: zbornik radova : 9. Savjetovanje za narodne knjižnice u republici Hrvatskoj / [uredile Dunja Marija Gabriel, Jelica Leščić]. Zagreb: Nacionala i sveučilišna knjižnica, 2015. Str. 379-384.

Morić Filipović, Ivana; Martina Dragija-Ivanović. Vrednovanje utjecaja sveučilišnih knjižnica u Hrvatskoj : istraživanje utjecaja zbirki i usluga sveučilišnih knjižnica na akademski uspjeh studenata. // Vjesnik bibliotekara Hrvatske 54, 4(2011), 1-22. [citirano: 2017-05-02] Dostupno i na http://www.hkdrustvo.hr/ $\mathrm{vbh} / \mathrm{broj} / 105$.

Novak, Helena. Anketno istraživanje zadovoljstva Gradske knjižnice Zadar. // Vjesnik bibliotekara Hrvatske 53, 3/4(2010), 140-157. [citirano: 2017-05-02] Dostupno i na http://www.hkdrustvo.hr/vbh/broj/102.

NSK ANKETA '94 : studija korisnika i korištenja NSK u Zagrebu [citirano: 201705-02]. Dostupno na http://tefkos.comminfo.rutgers.edu/NSK_report_94.pdf.

NSK ANKETA '99: studija korisnika i korištenja NSK u Zagrebu [citirano: 201705-02]. Dostupno na http://tefkos.comminfo.rutgers.edu/NSK_report 99.pdf.

Pavlinić, Silva; Jasna Horvat. Stupanj zadovoljenja potreba korisnika knjižničnim uslugama - na osnovi provedene ankete u Gradskoj i sveučilišnoj knjižnici Osijek. // Korisnici u 21. stoljeću - izazov za knjižničarsku struku : radni materijali / 31. skupština Hrvatskoga knjižničarskog društva, međunarodni skup, Zadar, 7.-10. listopada 1998. [Zagreb?] : Hrvatsko knjižničarsko društvo, [1998.?]. Str. 95-96.

Petr Balog, Kornelija; Gordana Gašo. Istraživanje zadovoljstva korisnika u knjižnici Filozofskog fakulteta u Osijeku - uspijevamo li ih zadovoljiti? // Libellarium 9, 1(2016), 59-88. [citirano: 2017-05-02] Dostupno i na http://www.libellarium.org/index.php/libellarium/article/view/243.

Petr Balog, Kornelija. Korisnici i korištenje knjižničnih usluga u knjižnici Pedagoškog fakulteta Sveučilišta Josipa Jurja Strossmayera u Osijeku : magistarski rad. Zagreb : vlast. nak1., 1999.

Petr, Kornelija. Uspješnost poslovanja knjižnice Pedagoškog fakulteta u Osijeku: zadovoljstvo korisnika Knjižnicom i njezinim uslugama: // Vjesnik bibliotekara Hrvatske 43, 4(2000), 80-90. 
Petrić, Danijela. Osobno, promotivno i elektronički posredovano komuniciranje s korisnicima u knjižnici. // Podravina: časopis za multidisciplinarna istraživanja, 1, 1(2002), 45-74. [citirano: 2017-05-02] Dostupno i na http://hrcak.srce. hr/index.php?show=toc\&id_broj=6334.

Pikić, Aleksandra. Kvaliteta knjižnične usluge u visokoškolskoj knjižnici iz korisničke perspektive : doktorski rad [citirano 2017-05-02]. Zagreb : vlast. nak1., 2015. Dostupno i na https://darhiv.ffzg.unizg.hr/secure/cgi/users/login?target $=$ http $\% 3 \mathrm{~A} \% 2 \mathrm{~F} \% 2 \mathrm{Fdarhiv.ffzg.unizg.hr} \% 2 \mathrm{~F} 5710 \% 2 \mathrm{~F} 1 \% 2 \mathrm{FPikic}$ Doktorat.pdf.

Polak Bobić, Kristina; Zrinka Vitković. „Iz stare i nove knjižnice HAZU“: analiza i komparacija dvaju korisničkih istraživanja. // Knjižnice: kamo i kako dalje? : pohrana i zaštita knjižnične građe, profesija "knjižničar"???, usluge i korisnici : zbornik radova / 12. dani specijalnih i visokoškolskih knjižnica, Opatija, 11.14. svibnja 2011. ; uredile Alisa Martek i Elizabeta Rybak Budić ; [prijevod na engleski jezik Tea Fluksi]. Zagreb: Hrvatsko knjižničarsko društvo, 2013. Str. 199-214.

Sabolović-Krajina, Dijana. Narodna knjižnica kao središte lokalne zajednice u suvremenom društvu : doktorska disertacija [citirano 2017-05-02]. Zagreb : vlast. nakl., 2016. Dostupno i na http://darhiv.ffzg.unizg.hr/6373/1/doktorski\%20rad\%20dijana\%20sabolovic\%20krajina.pdf.

Sabolović-Krajina, Dijana; Ljiljana Ernečić; Marica Koržinek. Marketing u službi potreba korisnika knjižnice. // Korisnici u 21. stoljeću - izazov za knjižničarsku struku : radni materijali / 31. skupština Hrvatskoga knjižničarskog društva, međunarodni skup, Zadar, 7. - 10. listopada 1998. [Zagreb?] : Hrvatsko knjižničarsko društvo, [1998.?]. Str. 105-106.

Šapro Ficović, Marica. Djelovanje knjižnica pod opsadom u ratu : studija slučaja : Hrvatska 1991/1995. godine : doktorska disertacija. Zagreb : vlast. nak1., 2012.

Šapro-Ficović, Marica. Istraživanje korisnika u Narodnoj knjižnici Dubrovnik. // Vjesnik bibliotekara Hrvatske 43, 4(2000), 118-131.

Šapro-Ficović, Marica. Značenje slobodnog pristupa informacijama za korisnike narodnih knjižnica. // Slobodan pristup informacijama u službi kulturnog razvitka : zbornik radova / uredile Alemka Belan-Simić i Aleksandra Horvat. Zagreb : Hrvatsko knjižničarsko društvo, 2002. Str. 76-94.

Valentić, Mirjana. Zadovoljstvo korisnika uslugama visokoškolske knjižnice : diplomski rad [citirano: 2017-05-02]. Rijeka, 2015. Dostupno i na https://repository.ffri.uniri.hr/islandora/object/ffri\%3A341/datastream/PDF/view.

Vincek, Ivan. Istraživanje zadovoljstva korisnika Gradske knjižnice Novi Marof: diplomski rad [citirano 2017-05-02]. Osijek : vlast. nakl., 2016. Dostupno na https://repozitorij.unios.hr/islandora/object/ffos\%3A671.

Vrana, Radovan; Jasna Kovačević. Percepcija korisnika o knjižnici i knjižničnim uslugama kao temelj poslovne strategije knjižnice. // Vjesnik bibliotekara Hr- 
vatske 56, 3(2013), 23-46. [citirano: 2017-05-02] Dostupno i na http://www. hkdrustvo.hr/vbh/broj/110.

Vugrinec, Ljiljana. Istraživanje o zadovoljstvu korisnika uslugama bibliobusa. // Svezak: Časopis Društva knjižničara Bilogore, Podravine i Kalničkog prigorja 12, 12(2010) 15-17. [citirano: 2017-05-02] Dostupno i na http://www.drustvo-knjiznicara-pkp.hr/svezak/svezak12/svezak_12_2010.pdf.

\subsection{Elektroničke usluge}

(korištenje računala i interneta, e-knjige, elektroničkih baza podataka, mrežnog kataloga, mrežnih stranica knjižnica, istraživanja korisničkog ponašanja prilikom korištenja tih usluga - analiza log-datoteka, Google Analitics, korisničko označivanje)

Andrlić, Berislav; Robert Idlbek; Branka Kotur. WebPaC Gradske i sveučilišne knjižnice u Osijeku : studija uporabljivosti. // Vjesnik bibliotekara Hrvatske 49, 2(2006), 50-60. [citirano: 2017-05-02] Dostupno i na http://www.hkdrustvo.hr/vbh/broj/93.

Arh, Evgenia; Dejana Golenko; Branka Pemper. Digitalni urođenici u sveučilišnoj zajednici: istraživanje na Sveučilištu u Rijeci. // Knjižnice: kamo i kako dalje? : pohrana i zaštita knjižnične građe, profesija "knjižničar"???, usluge i korisnici : zbornik radova / 12. dani specijalnih i visokoškolskih knjižnica, Opatija, 11.14. svibnja 2011. ; uredile Alisa Martek i Elizabeta Rybak Budić ; [prijevod na engleski jezik Tea Fluksi]. Zagreb: Hrvatsko knjižničarsko društvo, 2013. Str. 187-198.

Bačić, Mira; Zagorka Majstorović. Baze podataka s cjelovitim člancima i korisnici Nacionalne i sveučilišne knjižnice. // 8. seminar Arhivi, knjižnice, muzeji : mogućnosti suradnje u okruženju globalne informacijske infrastrukture : zbornik radova / uredila Tinka Katić. Zagreb : Hrvatsko knjižničarsko društvo, 2005. Str. 121-127.

Buzina, Tanja; Karolina Holub. Mrežne stranice digitalnog arhiva hrvatskih mrežnih publikacija : istraživanje korištenja. // 11. seminar Arhivi, knjižnice, muzeji : mogućnosti suradnje u okruženju globalne informacijske infrastrukture : zbornik radova / uredila Mirna Willer. Zagreb : Hrvatsko knjižničarsko društvo, 2008. Str. 113-127.

Cvitković, Aleksandra. Korištenje društvene mreže Facebook u slobodnom vremenu mladih u Knjižnicama grada Zagreba: diplomski rad. Zadar : vlast. nakl., 2012.

Džaja Vrban, Nada; Jasna Kovačević. Kompjutorizacija i korisnici u Knjižnici i čitaonici Bogdana Ogrizovića. // Korisnici u 21. stoljeću - izazov za knjižničarsku struku : radni materijali / 31. skupština Hrvatskoga knjižničarskog društva, međunarodni skup, Zadar, 7. - 10. listopada 1998. [Zagreb?] : Hrvatsko knjižničarsko društvo, [1998.?]. Str. 78. 
Erjavec, Karmen. Korisnici interneta u slovenskim narodnim knjižnicama. // Slobodan pristup informacijama : 13. i 14. okrugli stol : zbornik radova / uredile Tea Grašić-Kvesić i Ivana Hebrang Grgić ; [prijevod na engleski jezik Alka Krvavac, Snježana Šute] ; [prijevod sa slovenskog i srpskog jezika Adela Ćurlić, Tea Grašić-Kvesić, Ivana Hebrang Grgić]. Zagreb : Hrvatsko knjižničarsko društvo, 2014. Str. 176-186.

Furi, Ivana. Ponašanje studenata prilikom traženja informacija u elektroničkom okruženju: diplomski rad [citirano 2017-05-02]. Osijek : vlast. nakl., 2014. Dostupno i na https://repozitorij.ffos.hr/islandora/object/ffos:820.

Gašo, Gordana, Ivana Čadovska, Maja Klajić. Stavovi znanstveno-nastavnog osoblja o institucijskom repozitoriju : primjer Repozitorija Filozofskog fakulteta $\mathrm{u}$ Osijeku. // Zajedničko, a različito : načela interoperabilnosti u AKM zajednici / [19. seminar Arhivi, knjižnice, muzeji: mogućnosti suradnje u okruženju globalne informacijske infrastrukture, Rovinj, 25.-27. studenoga 2015.] ; gošće urednice Vesna Hodak, Alisa Martek, Renata Petrušić ; [prijevod s engleskog Andreja Dragojević, Alisa Martek]. Zagreb : Hrvatsko knjižničarsko društvo, 2016. Str. 15-45.

Holcer, Dunja. Hrvatske narodne knjižnice i društvene mreže : doktorski rad. Zagreb : vlast. nakl., 2015. Dostupno i na http://darhiv.ffzg.unizg.hr/5713/1/Dunja_Holcer_Doktorski_rad.pdf.

Jelić, Ivan. Nove usluge mrežnog kataloga kao oslonac razvoja i poboljšanja kvalitete usluga u knjižnicama. // Vjesnik bibliotekara Hrvatske. 58,1-2(2015), 209-220. [citirano: 2017-05-02] Dostupno i na http://hrcak.srce.hr/index. php?show=toc\&id_broj=11608.

Konjević, Sofija; Ivana Pažur. Korištenje i prihvaćanje elektroničkih časopisa : istraživanje korisnika Knjižnice Instituta „Ruđer Bošković“. // Vjesnik bibliotekara Hrvatske 45, 3/4(2002), 169-183.

Lazzarich, Lea. Kako mrežne stranica knjižnica mogu pomoći ili odmoći u promidžbi? // Vjesnik bibliotekara Hrvatske 46, 3/4(2003), 119-124. [citirano: 2017-05-02] Dostupno i na http://www.hkdrustvo.hr/vbh/broj/87.

Lisek, Jadranka; Tihana Brkljačić. Tko nam to dolazi? Korištenje informacijske i komunikacijske tehnologije (ICT) i stilovi učenja kod novoupisanoga naraštaja studenata FER-a. // Vjesnik bibliotekara Hrvatske 55, 3/4(2012), 29-52. [citirano: 2017-05-02] Dostupno i na http://www.hkdrustvo.hr/vbh/broj/108.

Lončar, Marina. Elektronička knjiga i elektronički čitač i kao nova usluga : iskustva i perspektive. // Vjesnik bibliotekara Hrvatske 56, 3(2013), 101-126. [citirano: 2017-05-02] Dostupno i na http://www.hkdrustvo.hr/vbh/broj/110.

Majlinger Tanocki, Inge. Pristup arhivima hrvatskih knjižnica na internetu s posebnim osvrtom na sadržajnu analizu: magistarski rad. Zagreb: vlast. nakl., 2012. 
Majlinger Tanocki, Inge; Kornelija Petr Balog. Predmetni pristup u mrežnim katalozima hrvatskih narodnih knjižnica : studija uporabljivosti. // Knjižničarstvo: glasnik Društva knjižničara Slavonije i Baranje 17, 1(2013), 5582. [citirano: 2017-05-02] Dostupno na http://www.knjiznicarstvo.com. hr/2013/06/08/209-majlinger-tanocki-petr-balog/.

Markulin, Helena; Jelka Petrak; Marijan Šember. Internet i studenti Medicinskog fakulteta u Zagrebu : analiza navika triju naraštaja studenata. // Vjesnik bibliotekara Hrvatske 57, 4(2014), 65-78. [citirano: 2017-05-02] Dostupno i na http://www.hkdrustvo.hr/vbh/broj/113.

Markulin, Helena; Jelka Petrak; Marija Šember. Internet i studenti Medicinskog fakulteta. // Vjesnik bibliotekara Hrvatske 43, 4(2000), 179-184.

Matovina, Jagoda; Sanja Pavlaković; Ivanka Stričević. Besplatni Internet za sve : internet u narodnoj knjižnici. // Vjesnik bibliotekara Hrvatske 45, 3/4(2002), 184-194.

Mihalić, Marina. Vrednovanje digitalnih informacijskih izvora i usluga u knjižnicama : doktorska disertacija. Zagreb : vlast. nakl., 2011.

Milek, Vida. Spremnost korisnika za korištenje kompjutora. // Korisnici u 21. stoljeću - izazov za knjižničarsku struku : radni materijali / 31. skupština Hrvatskoga knjižničarskog društva, međunarodni skup, Zadar, 7. - 10. listopada 1998. [Zagreb?] : Hrvatsko knjižničarsko društvo, [1998.?]. Str. 93-94.

Papić, Anita. Modeli konvergencije e-usluga visokoškolskih knjižnica i sustava za upravljanje učenjem : doktorska disertacija. Zagreb : vlast. nakl., 2012.

Semenski, Vikica. Dostupnost mrežnih sadržaja na primjeru mrežnih mjesta www. kgz.hr i www.human-rights.hr. // 11. seminar Arhivi, knjižnice, muzeji : mogućnosti suradnje u okruženju globalne informacijske infrastrukture : zbornik radova / uredila Mirna Willer. Zagreb : Hrvatsko knjižničarsko društvo, 2008. Str. 180-189.

Stojanovski, Jadranka: Što (ne) znamo o našim virtualnim korisnicima. // Vjesnik bibliotekara Hrvatske 45, 3/4(2002), 143-154.

Stričević, Ivanka. Slobodan pristup informacijama za djecu i mladež: granice i odgovornosti. // Slobodan pristup informacijama u službi kulturnog razvitka : zbornik radova / uredile Alemka Belan-Simić i Aleksandra Horvat. Zagreb : Hrvatsko knjižničarsko društvo, 2002. Str. 141-155.

Šojat-Bikić, Maja. Modeliranje digitalnih zbirki i digitalnih proizvoda: sadržajno-korisnički aspekt komuniciranja kulturne baštine u digitalnom obliku. ${ }^{3} / /$ Muzeologija 50 (2013), 17-516. [citirano: 2017-05-02] Dostupno i na http:// hrcak.srce.hr/index.php?show=toc\&id_broj $=11177$.

3 Na stranici 370 navedeno je istraživanje posjetitelja/korisnika zagrebačkih baštinskih ustanova, među kojima su anketirani korisnici Knjižnica grada Zagreba. 
Špiranec, Sonja; Tomislav Ivanjko. Predmetni jezici s korisničkim jamstvom: što možemo naučiti od folksnomija? : preliminarno istraživanje. ${ }^{4} / / 15$. seminar Arhivi, knjižnice, muzeji : mogućnosti suradnje u okruženju globalne informacijske infrastrukture : zbornik radova / uredili Damir Hasenay i Maja Krtalić. Zagreb : Hrvatsko knjižničarsko društvo, 2012. Str. 57-72.

Šupraha-Perišić, Milka. Korisnici interneta u narodnoj knjižnici : primjer Gradske biblioteke Rijeka. // Međunarodno savjetovanje Knjižnice europskih gradova u 21. St. Varaždin: Godišnjak Gradske knjižnice Metel Ožegović, 1998. Str. 205-210.

\subsection{Edukacija korisnika}

Bekavac, Mladenka. Izobrazba studenata za samostalno pronalaženje medicinskih informacija. // Edukacija korisnika i knjižničnoga osoblja : zbornik radova / 5. dani specijalnoga knjižničarstva Hrvatske, Opatija, 10. i 11. travnja 2003. ; uredila Maja Jokić ; [prijevod na engleski jezik Jasminka Fajdetić-Kinnard]. Zagreb : Hrvatsko knjižničarsko društvo, 2004. Str. 199-204.

Frigo-Haltrich, Irena. Istraživanje potreba korisnika knjižnice Fakulteta političkih znanosti za edukacijom. // Edukacija korisnika i knjižničnoga osoblja : zbornik radova / 5. dani specijalnoga knjižničarstva Hrvatske, Opatija, 10. i 11. travnja 2003. ; uredila Maja Jokić ; [prijevod na engleski jezik Jasminka Fajdetić-Kinnard]. Zagreb : Hrvatsko knjižničarsko društvo, 2004. Str. 186-198.

Jokić, Maja. Obrazovanje korisnika specijalnih i visokoškolskih knjižnica - stanje u Hrvatskoj = Izobraževanje uporabnikov specialnih in visokošolskih knjižnic - stanje na Hrvaškem // Vloga specialnih knjižnic pri pospeševanju družbenega in gospodarskega razvoja, Izobraževalni management v specialnih knjižnicah : zbornik referatov / Češnovar, Nada (ur.). Ljubljana : Narodna in univerzitetna knjižnica Ljubljana, 2002. Str. 107-116.

\subsection{Razne druge aktivnosti informativne službe}

(tribine, izložbe, čitateljski klubovi, promotivne aktivnosti, obrazovanje na daljinu, suradnja s drugim institucijama - npr. domovi umirovljenika, zatvori)

Bagarić, Željka. Model suradnje narodnih knjižnica i zatvorskog sustava u Republici Hrvatskoj : doktorska disertacija. Zagreb : vlast. nakl., 2013.

Lukačević, Srđan; Dubravka Pađen-Farkaš. Oblikovanje pisanih promotivnih materijala Gradske i sveučilišne knjižnice. // Knjižničarstvo: glasnik Društva knjižničara Slavonije i Baranje 17, 2(2013), 37-48. [citirano: 2017-05-02]

4 Navedeni autori objavili su još radova u kojima se korisničko označivanje ne istražuje samo u knjižnicama. 
Dostupno na http://www.knjiznicarstvo.com.hr/2014/05/08/225-lukacevic-paden-farkas/.

Može, Snježana. Tribina u funkciji marketinškog programa narodnih knjižnica : magistarski rad. Varaždin : vlast. nakl., 1993.

Nenadić, Andrija. Mogućnosti visokoškolskih knjižnica u procesima obrazovanja na daljinu : magistarski rad [citirano 2017-05-02]. Zagreb : vlast. nakl., 2005. Dostupno i na http://beta.bib.irb.hr/pregled/znanstvenici/281131.

\subsection{Informacijska pismenost i informacijsko ponašanje}

(stupanj informacijskih kompetencija/znanja i ponašanje korisnika pri odabiru informacijskih kanala i izvora)

Bračanov, Antica; Vesna Golubović; Dunja Seiter-Šverko. Istraživanje informacijske pismenosti studenata u Nacionalnoj i sveučilišnoj knjižnici u Zagrebu. // Vjesnik bibliotekara Hrvatske 57, 4(2014), 45-64. [citirano: 2017-05-02] Dostupno i na http://www.hkdrustvo.hr/vbh/broj/113.

Bunić, Sanja. Suradnja Knjižnica grada Zagreba s knjižnicama umirovljeničkih domova. // Slobodan pristup informacijama : 2. i 3. okrugli stol : zbornik radova / uredile Alemka Belan-Simić i Aleksandra Horvat. Zagreb : Hrvatsko knjižničarsko društvo, 2004. Str. 143-153.

Dimzov, Snježana. Uloga sveučilišne knjižnice u digitalnom okruženju s obzirom na informacijsko ponašanje studenata humanističkih znanosti: doktorska disertacija. Zadar: vlast. nakl., 2016.

Ivanović, Marija; Nada Kušić. Recepcija narodne knjižnice u odrasloj populaciji [citirano: 2017-05-02]. Dostupno na http://www.knjiznica-vg.hr/galzenica/ wp-content/uploads/sites/4/2014/12/plakat2.pdf.

Krajna, Tamara; Kata Husnjak. Knjižničari - partneri u procesu obrazovanja. // Partnerstva u specijalnim i visokoškolskim knjižnicama: zbornik radova / 7. dani specijalnih i visokoškolskih knjižnica, Opatija, 21-22. travnja 2005. ; uredile Irena Pilaš i Alisa Martek ; [prijevod na engleski jezik Jasminka Fajdetić-Kinnard]. Zagreb : Hrvatsko knjižničarsko društvo, 2007. Str. 79-87.

Kuić, Ivanka. Odnos prema informacijama kao paradigma za proučavanje ponašanja i stavova korisnika na primjeru Sveučilišne knjižnice u Splitu. // Korisnici u 21. stoljeću - izazov za knjižničarsku struku : radni materijali / 31. skupština Hrvatskoga knjižničarskog društva, međunarodni skup, Zadar, 7. - 10. listopada 1998. [Zagreb?] : Hrvatsko knjižničarsko društvo, [1998.?]. Str. 90-91.

Markulin, Helena. Uloga medicinskog knjižničara u postupku pronalaženja znanstveno utemeljenih dokaza potrebnih u medicinskoj praksi : doktorska disertacija. Zagreb : vlast. nakl., 2012.

Rubinić, Dora; Ivanka Stričević. Informacijsko opismenjavanje studenata: potrebe i perspektive. // Knjižnice: kamo i kako dalje? : pohrana i zaštita knjižnične 
građe, profesija "knjižničar"???, usluge i korisnici : zbornik radova / 12. dani specijalnih i visokoškolskih knjižnica, Opatija, 11.-14. svibnja 2011. ; uredile Alisa Martek i Elizabeta Rybak Budić ; [prijevod na engleski jezik Tea Fluksi]. Zagreb: Hrvatsko knjižničarsko društvo, 2013. Str. 173-186.

Rubinić, Dora; Ivanka Stričević. Visokoškolska knjižnica u programima informacijskog opismenjivanja studenata : istraživanje programa Sveučilišne knjižnice Sveučilišta Karl-Franzens Graz. // Vjesnik bibliotekara Hrvatske 54, 4(2011), 23-48. [citirano: 2017-05-02] Dostupno i na http://www.hkdrustvo.hr/vbh/ broj/105.

Salatić, Blanka. Razina informacijske pismenosti studenata osječkog sveučilišta. // Knjižnice: kamo i kako dalje? : članstvo u EU - knjižničari gdje smo?, produktivnost znanstvene zajednice, obrazovanje korisnika, knjižnice u vremenu recesije - kako preživjeti ?: zbornik radova / 13. dani specijalnih i visokoškolskih knjižnica, Opatija, 15.-18. svibnja 2013. ; uredile Ivana Hebrang Grgić i Vesna Spac.; [prijevod na engleski jezik Tea Fluksi]. Zagreb : Hrvatsko knjižničarsko društvo, 2014. Str. 243-251.

Škorić, Lea; Marijan Šember; Helena Markulin; Jelka Petrak. Informacijska pismenost u nastavnom programu diplomskog studija Medicinskog fakulteta Sveučilišta u Zagrebu. // Vjesnik bibliotekara Hrvatske 55, 3/4(2012), 17-28. [citirano: 2017-05-02] Dostupno i na http://www.hkdrustvo.hr/vbh/broj/108.

\subsection{Zgrada i prostori knjižnice}

Hercog, Tanja. Knjižnični prostor kao čimbenik kvalitete visokoškolske knjižnice: na primjeru knjižnice Filozofskog fakulteta u Osijeku: diplomski rad. Osijek : vlast. nakl., 2011.

Marijanović, Luka. Fizički prostor knjižnice Filozofskog fakulteta u Osijeku: stanje i očekivanja: diplomski rad [citirano 2017-05-02]. Osijek : vlast. nakl., 2016. Dostupno i na https://repozitorij.ffos.hr/islandora/object/ffos\%3A700.

\section{Zaključak}

Ukupno je popisano 147 znanstvenih i stručnih radova koji se bave istraživanjem knjižničnih usluga iz perspektive korisnika. Analizirajući godine provedenih istraživanja razvidan je porast broja istraživanja od 2010. godine, a najviše ih je objavljeno u posljednjih šest godina, kako je prikazano na slici 1 . U ranijem razdoblju ističe se 1998. godina, što se može objasniti objavljivanjem većeg broja radova vezanih uz temu 31. skupštine Hrvatskog knjižničarskog društva - korisnici u 21. stoljeću. ${ }^{5}$

5 Korisnici u 21. stoljeću - izazov za knjižničarsku struku : radni materijali / 31. skupština Hrvatskoga knjižničarskog društva, međunarodni skup, Zadar, 7. - 10. listopada 1998. [Zagreb?] : 


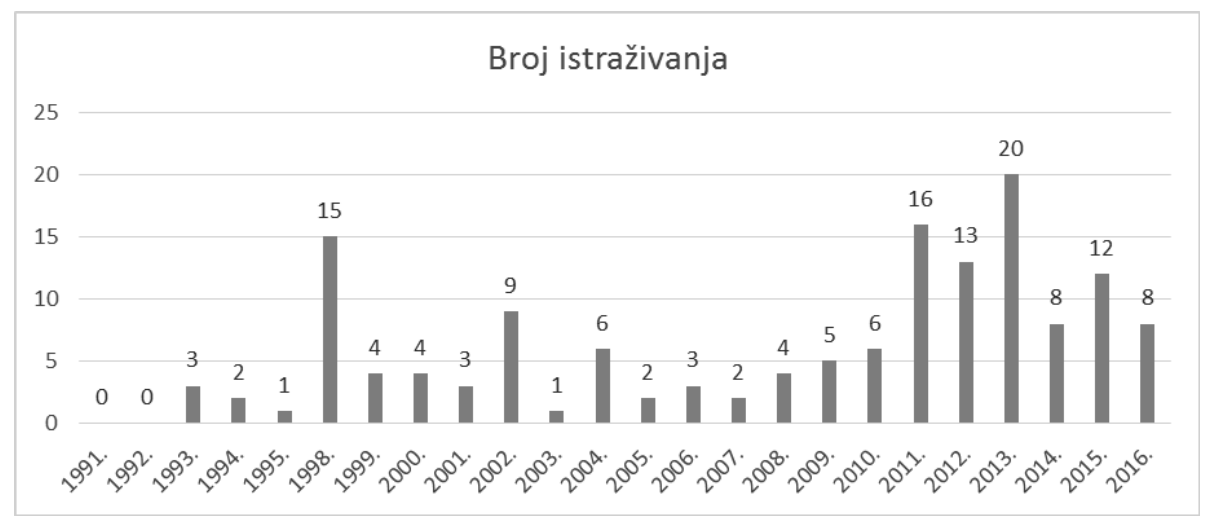

Slika 1. Broj istraživanja u knjižnicama po godinama

Veliku ulogu u porastu broja istraživanja, prvenstveno u visokoškolskim knjižnicama u Republici Hrvatskoj, odigralo je uvođenje bolonjskog procesa. ${ }^{6} \mathrm{U}$ središte pozornosti dolazi unapređivanje kvalitete nastavnog i znanstvenog procesa, gdje važnu ulogu imaju visokoškolske knjižnice koje počinju kontinuirano istraživati potrebe svojih korisnika, uz dodatni poticaj za istraživanja i drugim vrstama knjižnica kroz zajedničke projekte. ${ }^{7}$

Iz slike 2 vidljivo je da su najzastupljenije teme u istraživanjima bile zadovoljstvo korisnika i percepcija kvalitete knjižničnih službi i usluga (40 radova), zatim čitateljski interesi i informacijske potrebe korisnika (30) i elektroničke usluge (29). Iako se elektroničke usluge nalaze među tri najbrojnije teme (dijelom zato što obuhvaćaju i korisničko ponašanje prilikom korištenja tih usluga), za očekivati je da u svjetlu novih informacijskih tehnologija i poslovanja knjižnica koje trebaju pronalaziti vlastite odgovore na promjene u informacijskom području one budu intenzivnije istraživane (npr. o WebPacu imamo samo dva istraživanja, a o ponašanju korisnika na mrežnim stranicama preko analize log-datoteka samo jedno istraživanje). Također je malen broj istraživanja informacijske pismenosti korisnika, kao i njihova informacijskog ponašanja općenito. Iznenađuje mali broj radova $\mathrm{s}$ temom edukacija korisnika: pronađena su samo tri rada, i to samo u visokoškolskim knjižnicama. Informacijska služba, koja uz neposredan rad s korisnicima i rješavanje njihovih upita, organizira i provodi razne druge aktivnosti (čitateljski

Hrvatsko knjižničarsko društvo, [1998.?].

6 Vidi u Plašćak, Bernardica; Kornelija Petr Balog. Per aspera ad astra: trnovit put jedne fakultetske knjižnice prema kvaliteti. // Vjesnik bibliotekara Hrvatske 54, 1/2(2011), 67-92. [citirano 2017-05-02] Dostupno i na http://www.hkdrustvo.hr/vbh/broj/103.

7 Badurina, Boris; Martina Dragija Ivanović; Maja Krtalić. Vrednovanje knjižničnih službi i usluga akademskih i narodnih knjižnica. // Vjesnik bibliotekara Hrvatske 53, 1(2010), 47-63. [citirano 2017-05-02] Dostupno i na http://www.hkdrustvo.hr/vbh/broj/100. 
klubovi, izložbe, tribine, promotivne aktivnosti, suradnje s drugim institucijama), zastupljena je s ukupno 16 radova, od čega se samo četiri rada odnose na te druge aktivnosti.

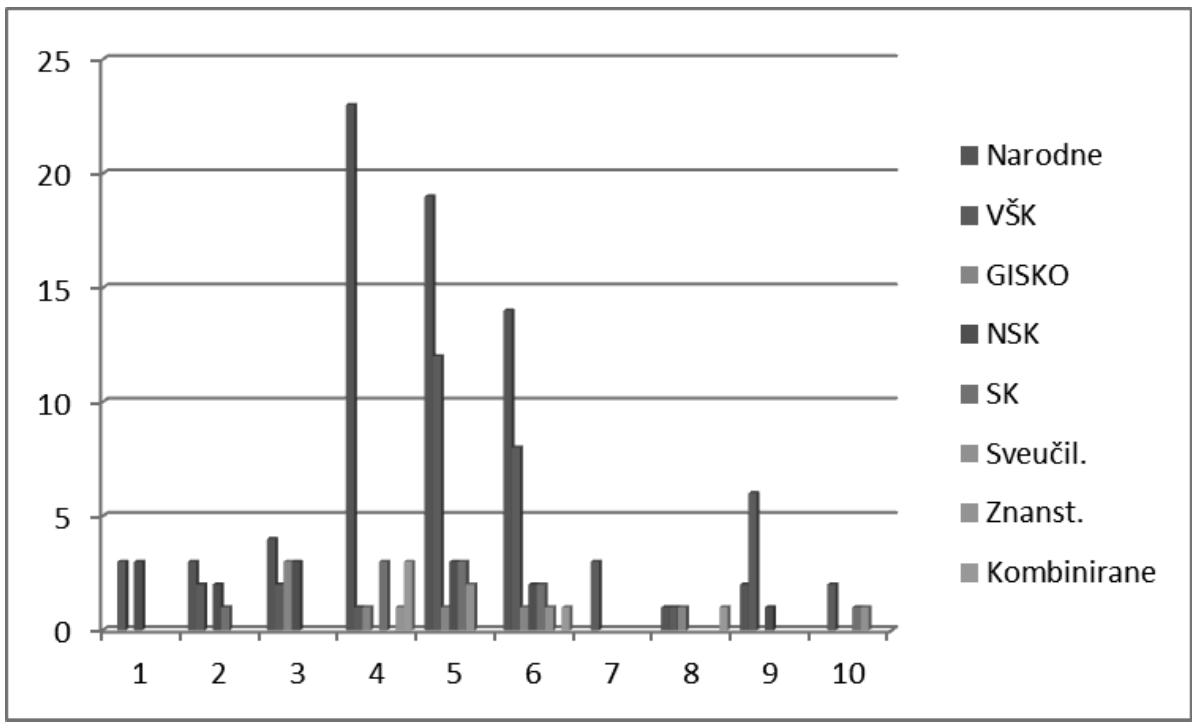

Slika 2. Teme koje su istraživane u pojedinim vrstama knjižnica

Iako su narodne knjižnice prisutne s najviše radova u tri najistraživanije teme, samo neke kontinuirano mjere zadovoljstvo i percepciju kvalitete svojih usluga. ${ }^{8}$ Slična je situacija i s visokoškolskim knjižnicama. Možemo izuzeti Knjižnicu Filozofskog fakulteta Osijek i Nacionalnu i sveučilišnu knjižnicu u Zagrebu kao primjere dobre prakse u provođenju kontinuiranih istraživanja.

Razloge za još uvijek nedostatno razvijenu kulturu vrednovanja u hrvatskim knjižnicama navodi autorica Kornelija Petr Balog9, ukazujući na činjenicu da knjižnice nemaju dovoljno djelatnika koje mogu prerasporediti na poslove vrednovanja, a da pritom ne zanemare svoje temeljne dužnosti, kao i nedostatak educiranosti djelatnika za provođenje istraživanja. Ne manje važan razlog jest i izostanak konkretnog plana za djelovanje u smjeru mjerenja i prikupljanja podataka za istraživanja.

8 Vidi: Kovačević, Jasna; Radovan Vrana. Pogled na knjižnične usluge iz perspektive korisnika. // Vjesnik bibliotekara Hrvatske 58, 1/2(2015), 135-160. [citirano: 2017-05-02] Dostupno i na http://www.hkdrustvo.hr/vbh/broj/114.

9 Petr Balog, Kornelija. Kultura vrednovanja kao dio organizacijske kulture hrvatskih knjižnica // Vjesnik bibliotekara Hrvatske 55, 1(2012), 1-28. [citirano: 2017-05-02] Dostupno i na http:// www.hkdrustvo.hr/vbh/broj/106. 
Jedan od kriterija za odabir i analizu radova u bibliografiji bile su i metode za prikupljanje podataka. U radovima su zastupljene sljedeće metode: anketa, analiza sadržaja, intervju, promatranje, fokus-grupa, analiza posjećenosti mrežnih mjesta, kvantitativna analiza korisničkih upita/posudbe (statistika potražnje i korištenja) i kombinirana metoda (npr. anketa i promatranje ili anketa i kvantitativna analiza).

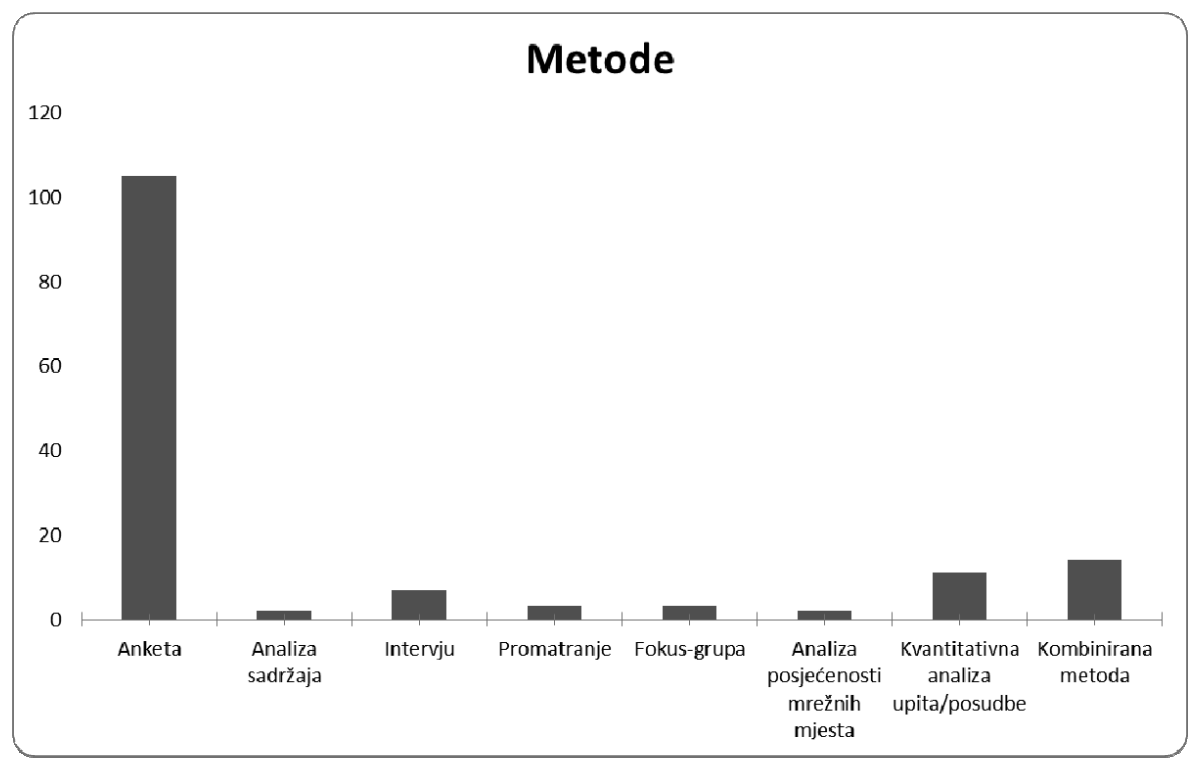

Slika 3. Najčešće korištene metode za prikupljanje podataka

Iz slike 3 vidljiva je dominacija ankete kao kvantitativne metode - od 147 radova, ona se javlja kao jedina metoda u 105 radova. Na drugom je mjestu kombinirana metoda (14), zatim kvantitativna analiza korisničkih upita/posudbe (11), intervju (7), promatranje (3), fokus-grupa (3), analiza sadržaja (2) i analiza mrežnih mjesta (2). Analiza radova pokazala je malu korištenost kvalitativne metodologije, koja je izuzetno važna, naročito u smislu vrednovanja.

Nadamo se da će ova bibliografija biti koristan poticaj pri odabiru tema i metoda za nova istraživanja u knjižnicama. 


\section{LITERATURA}

Badurina, Boris; Martina Dragija Ivanović; Maja Krtalić. Vrednovanje knjižničnih službi i usluga akademskih i narodnih knjižnica. // Vjesnik bibliotekara Hrvatske 53, 1(2010), 47-63. [citirano 2017-05-02] Dostupno i na http://www.hkdrustvo.hr/vbh/ broj/100

Järvelin, Kalervo; Pertti Vakkari. The classification scheme: appendix 1. 1993. [citirano: 2017-05-05]. // International library and information science research : a comparison of national trends / by Maxine K. Rochester and Pertti Vakkari [on behalf of IFLA's] Section on Library Theory and Research. [S. 1.] : International Federation of Library Associations and Instititions, cop. 2003. (IFLA professional reports ; nr. 82). Str. $27-$ 28. Dostupno na http:/www.ifla.org/VII/s24/pub/iflapr-82-e.pdf

Korisnici u 21. stoljeću - izazov za knjižničarsku struku : radni materijali / 31. skupština Hrvatskoga knjižničarskog društva, međunarodni skup, Zadar, 7.-10. listopada 1998. [Zagreb?] : Hrvatsko knjižničarsko društvo, [1998.?].

Kovačević, Jasna; Radovan Vrana. Pogled na knjižnične usluge iz perspektive korisnika. // Vjesnik bibliotekara Hrvatske 58, 1/2(2015), 135-160. [citirano: 2017-05-02] Dostupno i na http://www.hkdrustvo.hr/vbh/broj/114

Petr Balog, Kornelija. Kultura vrednovanja kao dio organizacijske kulture hrvatskih knjižnica // Vjesnik bibliotekara Hrvatske 55, 1(2012), 1-28. [citirano: 2017-05-02] Dostupno i na http://www.hkdrustvo.hr/vbh/broj/106

Plašćak, Bernardica; Kornelija Petr Balog. Per aspera ad astra: trnovit put jedne fakultetske knjižnice prema kvaliteti. // Vjesnik bibliotekara Hrvatske 54, 1/2(2011), 67-92. [citirano 2017-05-02] Dostupno i na http://www.hkdrustvo.hr/vbh/broj/103 